\title{
BUSINESS TRENDS OF HALAL AND THOYYIB FOOD DURING THE PANDEMIC: A REVIEW FROM ISLAMIC ECONOMICS IN PONGGOK AND JANTI TOURISM DESTINATIONS
}

\author{
Fredi Setyono \\ UIN Sunan Kalijaga Yogyakarta, Indonesia \\ 20208011007@student.uin-suka.ac.id
}

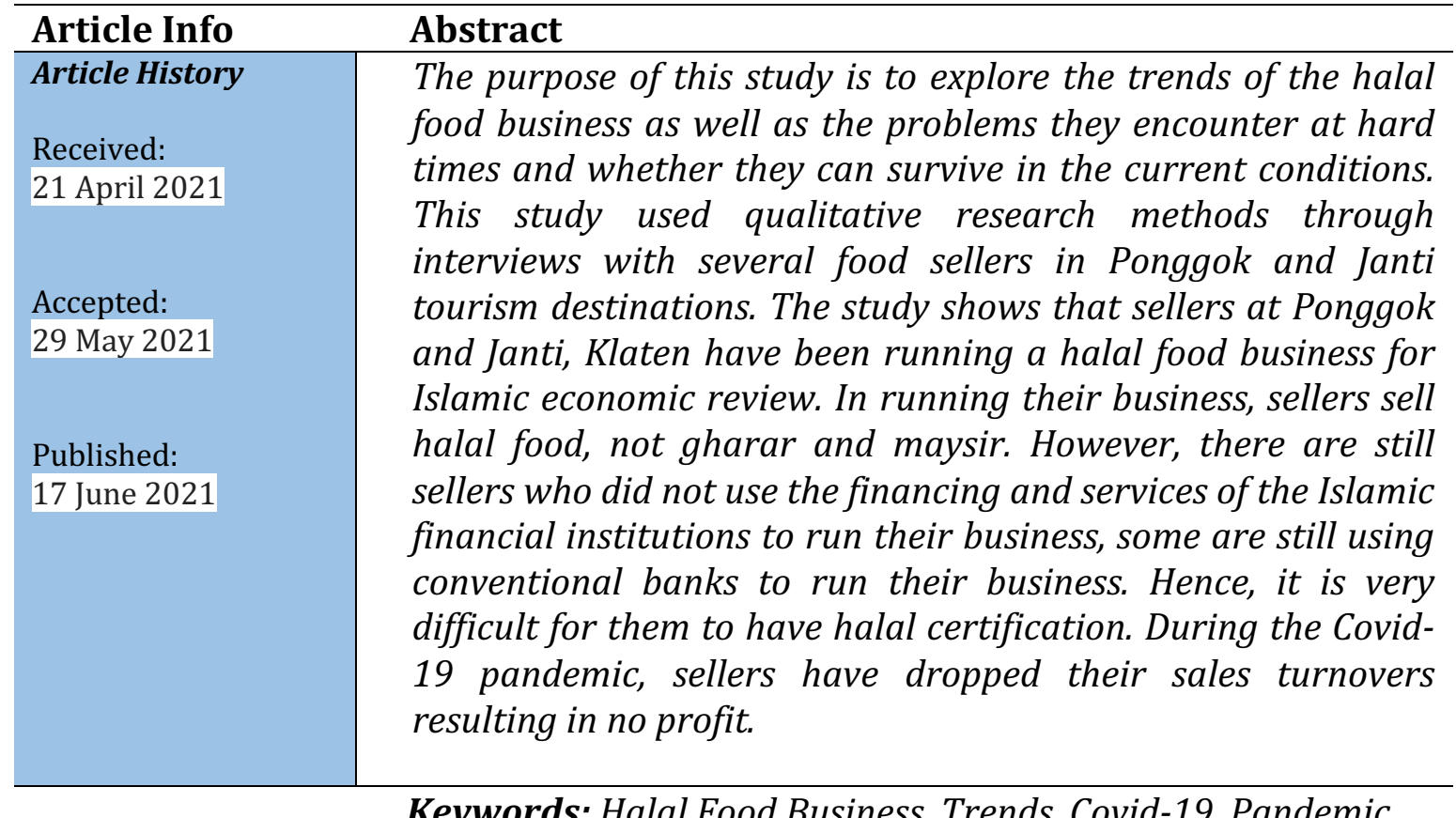

Keywords: Halal Food Business, Trends, Covid-19, Pandemic

\section{INTRODUCTION}

The business has developed, especially the sharia economy. This development is supported by government policies and regulations from the central and local governments. The development of the sharia economy cannot be separated from the halal food business that is the center of business expansion, especially in Muslim-majority countries. In Indonesia, the halal food business has become a concern since food sold needs a halal label. All food should be certified halal, be the food is processed in the form of ready-to-eat food, stalls, restaurants, or cafes as well as in the traditional side or street vendors. They indeed contribute to the economy in the region.

In Southeast Asia, the trend of Muslims visiting interesting places is increasing every year. The most popular places to visit are historical mosques, the ulama's place, as well as Islamic relics and natural sites. In Malaysia, among them are the National Mosque, Jamek Mosque, the Tuanku Mizan Zainal Abidin (Masjid Besi) in Kuala Lumpur, and historical mosques in other cities. In Indonesia, the most popular places visited by Muslims are mosques built or attached to the Wali 
Songo and other historic or beautiful mosques in the country. This trend is no different in Brunei and Singapore, apart from other popular venues that have emerged recently.

In recent decades, the boom in the tourism industry worldwide must be attributed to faster and cheaper transportation and accommodation to balance the increase in tourists in many countries, particularly in Southeast Asia. This trend has motivated developing countries in Southeast Asia to develop the tourism industry and attract tourists from the West as well as from Muslim countries to visit the region. Southeast Asia is considered to be the fastest-growing country in developing the tourism industry and with double-digit average growth every year. This situation is due to the rapid development of facilities and accommodation as well as a stable political situation in addition to the relatively low cost of living and a multiracial society (Wahyono \& Razak, 2020: 99).

The halal lifestyle has recently hit the world, not only in countries with a majority Muslim population but also in countries with a non-Muslim majority. Awareness of the fulfillment of halal food is increasing in the global arena along with the expansion of global halal tourism. It is not only limited to the tourism destination sector related to religious sites but the fulfillment of tourism needs. Global companies (multinational corporations) have now implemented a halal system such as Japan Airlines, Singapore Airlines, Qantas, Cathay Pacific (Hong Kong), America Airlines that provide halal menus. This has been adopted in America, Australia, Japan, China, India, and Latin American countries. Specifically, Japan has very serious attention to the development of halal trends in which Japan held the Japan Halal Expo. The expo is always crowded and thereby is quite successful in attracting the attention and interest of various parties. Japan Halal Expo is a largescale exhibition that displays halal products made in Japan. Currently, 350 restaurants in Japan have served halal food, 54 of which are special restaurants of Japanese food (Warto A.S., 2020: 275).

The demand for halal products inside and outside the country has increased from year to year. The demand for halal food products in Asia such as in Japan is also increasing. The same happened to other halal products such as the demand for cosmetic products among Muslim women has increased significantly. In 2014, the world's demand for halal cosmetic products was USD 54 billion and within 6 years, it is expected to increase to USD 80 billion in 2020. Likewise, in Europe, for example in France, the rapid growth of the Muslim population linearly affects the growth in demand for halal products. This can be seen from the demand for halal products in the European market, which has increased 15\% per year since 2003, which at that time was valued at 15 billion euros (Nasrullah, 2018: 54). 
In New Zealand, awareness is one of the prerequisites for having a more 'authentic' halal food outlet. Businesses need to realize the significant relationship between food and cultures. Halal food attracts not only Muslim customers but also non-Muslim friends and relatives. Muslim consumers and Islamic organizations, such as the Federation of Islamic Associations of New Zealand called FIANZ, play an important role in developing halal awareness in the industry. They are required to make requests and provide information, as well as support restaurants and outlets that sell halal food. The more Muslim consumers in New Zealand demand halal products, the more likely the industry will provide them with halal food. Through education and communication, both industry and consumers can learn to understand and benefit from one another (Wan-Hassana \& Awangb, 2009: 398).

In Indonesia, halal certification is carried out by LPPOM-MUI (The Assessment Institute for Foods, Drugs, and Cosmetics- Indonesian Ulema Council). LPPOM-MUI is expected to provide ease of service in halal certification, especially the halal guarantee. This becomes an obstacles and difficulty especially for MSMEs or halal food sellers to register their products. In registering only, LPPOM wants halal industry players to prepare documents such as business legal, product matrix, internal audits, training, and so on. LPPOM and MUI are the only institutions entitled to issue halal certificates in Indonesia. In Indonesia, for food and beverage products that have been registered with BPOM, about $34.7 \%$ of products are cosmetic products (BPOM, 2020). According to LPPOM-MUI Statistical Data in 2019, the halal certification has reached 274,796 products, an increase of 70 thousand products in the previous year (LPPOM, 2019).

In Fatmasari's (2014) research, halal label and personal religiosity affect purchasing decisions of food products in Indonesia. The same research needs to be carried out in areas with a smaller Muslim population such as Bali or other areas. Seeing the lack of consideration for food factories to register their products with a halal certificate, it is important to formulate a regulation on halal certification for food products in Indonesia. This intends to guarantee not only its halalness but also its quality (Fatmasari Sukesti \& Mamdukh Budiman, 2014: 152).

In West Nusa Tenggara, the local government is very supportive of the development of Halal tourism. The West Nusa Tenggara Provincial Regulation Number 2 of 2016 is attribution and delegation of Article 18 paragraph (6) of the 1945 Constitution, Article 9 of Law Number 10 of 2009 concerning Tourism, Article 12 paragraph (3) letter b, and Article 236 Number 23 of 2014 concerning Regional Government, Article 5 of the Regulation of the Minister of Tourism and Creative Economy Number 2 of 2014 concerning Guidelines for Sharia Businesses Hotel Operations are efforts to develop tourism in these destinations while offering halal products and 
food (Jaelani et al., 2020: 769). Halal tourism is local content in West Nusa Tenggara. This is an encouragement for other regions to develop halal tourism.

The halal food business has become one of the trends that is preferred by the community since there are many entrepreneurs and sellers. MSMEs sell a lot of halal and thoyyib food since our society is predominantly Muslim and it will also have an effect on the benefit people. The halal and thoyib food business is one of the contributors to the development of halal tourism in Indonesia. Many foreign countries such as Korea and Japan have also prepared and stalls that provide halal food. This should be done in Indonesia.

Based on the State of Global Islamic Economy Report 2020, Indonesia is ranked fourth in the world for the halal tourism industry, ranked third for Muslim fashion, and ranked fifth for sharia finance. Unfortunately, Indonesian halal food is not yet in the top 10. The challenge is getting heavier when there is Covid 19 pandemic, especially for the MSME whose decreased profit. This also has an impact on the trade sector, especially the halal food business that is also affected by the ongoing economic crisis resulted from COVID-19. This study examined the halal food business by taking research on food sellers in the Ponggok and Janti tourism destinations. Ponggok is often used by the people of Klaten Regency to carry out the Padusan tradition (purifying themselves before Ramadan) as well as a place for breaking the fast in Ramadan because of the halal fish menu.

Along with the rapid trend of developing the halal food industry, problems are unavoidable. One of them is the economic crisis in 2020 due to the Covid-19 pandemic. The crisis is not only in the health sector but also in the economic sector that makes businesses strive to survive and struggle. Indeed, in Indonesia, there are many companies and industries that have experienced a decline in terms of income and sales. MSMEs were also affected by losses due to reduced turnover during the pandemic.

In doing business, there is gain or loss, and whether this happens in the trade sector, especially the halal food business, particularly in the tourism destination of Ponggok and Janti, Klaten. In running a business, it is also necessary to have the foundations of an Islamic economy or an Islamic economic review for material and non-material benefits in the form of rewards from Allah Almighty. Every business also needs cooperation from various parties to support including funds and others. This will also provide a stimulus in doing business, especially cooperation with Islamic financial institutions. Business should be halal and thoyyib.

\section{LITERATURE REVIEW}

Islam views buying and selling as a means of helping fellow human beings. People who are doing transactions are not seen as people who are looking for profit only but also helping their 
relatives. For the seller, they provide buyers the needs of the goods. As for the buyers, they provide profit to sellers. Thus, Islam allows it (Afandi, 2009: 54).

Besides that, the goods or products to sell are needed. Products are goods and/or services related to food, beverages, medicines, cosmetics, chemical products, biological products, genetically modified products, and consumer goods that are used, used, or utilized by the public. Halal products are products that have been declared halal following Islamic law. Halal Product Process (hereinafter abbreviated as PPH) is a series of activities to ensure the halalness of products including the supply of materials, processing, storage, packaging, distribution, sales, and product presentation (Kemenhan, 2014).

Based on a research conducted by Zahrah dan Fawaid (2019), halal products are products following Islamic law. Muslim awareness is very important for physical and spiritual health. The halal food industry in the 4.0 era is very easy to manage in terms of processing and selling it through the machine or artificial intelligence applications that ease Muslims or non-Muslims to choose halal food when ordering through social media such as Halal tests and other halal food applications (Halal Quest, Zabihah, Halal Crave, Halal Advisor, Halal Scan, Halal Trip, and Halal Spot).

In addition, there is a complete food laboratory used to test halal food products and the ingredients. There is also a group of the halal industry for the halal food industry and other halal products that provide halal ingredients and export to international markets and domestic management. The industrial revolution is increasingly sophisticated in giving changes to manufacturing, having a profound impact on globalization, conquering international boundaries and competition that can make halal food in Indonesia more famous, simplifying the ordering process, producing halal food, updating menus, expanding sales, multiplying seller's interest through online, opening widespread market, more efficient marketing, easing promotion, providing halal food ingredients, and increasing competitiveness (Zahrah \& Fawaid, 2019).

Thoyyib (Thyyibaat) means delicious, good, healthy, reassuring, not harming the body and mind, healthy (sufficient nutrition), proportionate, safe (does not cause the disease/safe for duniawi and ukhrown) (Musa, 2006). The potential of the halal industry is very good, this can be seen in the research of Nurdin et al. (2019) that revealed a promising potential for the halal industry in the city of Palu. The number of small industries engaged in the food sector is quite large. Although only around $16 \%$ have taken care of halal certificates, the results of their research show that several business actors want to take care of halal certificates. However, they do not get correct information about the process of obtaining a halal certificate. The majority of the Muslim population (84\%) is also an opportunity for small businesses in the food sector to market their products using the official halal label. An uncomplicated processing process with low cost and short time is also 
another potential for increasing halal-labeled products. Thus, the number of small businesses in the food sector that has halal certificates will increase.

Consumers in Indonesia are religious consumers and use religion as a reference for making choices about purchasing halal products. Setiawan \& Mauluddi (2019) shows that religiosity is a factor that has a significant effect on the purchase of halal products. Meanwhile, other factors not considered having insufficient influence to encourage consumers to do the same. This study suggested halal product providers in Indonesia ensure that the products they sell are halal by using Islamic attributes in their promotions.

According to Nurohman \& Qurniawati (2019), the dimensions of religiosity, namely ritualistic, experiential, and intellectual have a significant effect on the buying behavior of halal food. The aspect of religiosity is very important for buyers. It is hoped that sellers will also increase their religiosity in the form of giving alms and using Islamic financial institution financing to empower people to get more blessings. The seller should pay attention to social conditions and worship to get rewards and blessings from Allah Almighty.

During the pandemic, a strategy is also needed so that buyers will be loyal. This is also researched by Janti (2020) that we can imitate Japan, they are very welcome in the role of omotenashi or the friendly attitude shown by the Japanese people to tourists. This attitude is shown in the form of the availability of halal food, either in the restaurants or shops that serve halal food or other facilities that make it easier for Muslim tourists to enjoy the beauty of Japan. The increasing number of halal food in Japan is due to market demand instead of the increase in Japanese people becoming Muslims since Japan is more concerned with economic capital. It would be better if market demand for halal food such as in Japan could be assisted by a country with a majority Muslim population such as Indonesia.

Ulum (2018) examined sellers who weighed groceries following the Islamic Economic perspective in Soppeng Market, Soppeng Regency. The data analysis method used in this research was qualitative analysis with normative and sociological approaches. Research data obtained from primary data and secondary data with data collection techniques in the form of observation, documentation, interviews. The results showed that most sellers did not understand or even did not know about the correct scales in the Islamic Economic system. The sellers only prioritized profit and put aside ethical issues and ignored their responsibilities as sellers and harmed other buyers or sellers. Foodstuff sellers committed fraud and detriment buyers or consumers.

A study conducted by Marzuki \& Ramdaniah (2020) on the marketing strategy of basic food sellers in the Pasar Baru, Paiton. The method used is qualitative based on observation, interviews, and documentation. The results of their research show that there are some frauds in 
their marketing practices, such as the element of gharar or obscurity, coercion, and selling merchandise below the market price.

In this study, the researchers took several sources from the Quran, including:

Surah Al-Baqarah: 168 regarding halal food,

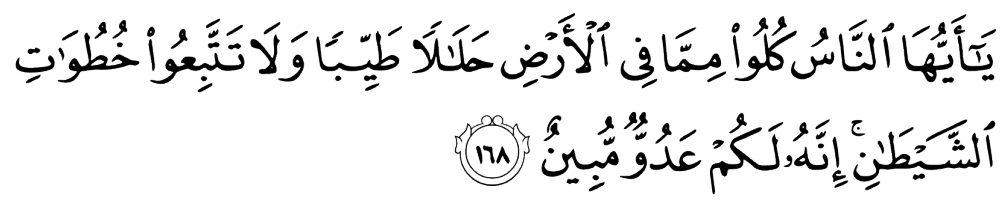

Translation: "O mankind! Eat of that which is lawful and clean on earth, and do not follow the footsteps of Shaitan (Satan) Verily, he is to you an open enemy." (2/ Al-Baqarab:168)

Surah An-Nahl: 115 about haram food,

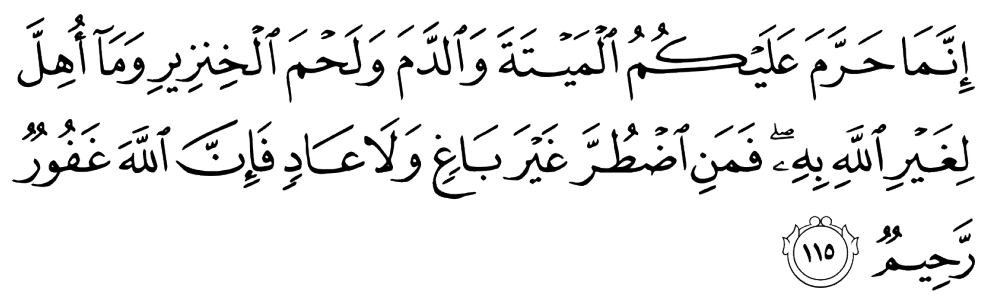

Translation: "He has only forbidden you what is dead, blood, flesh of swine and animal which is slaughtered in the name of others than Allah. But if one is forced by necessity (to eat), without willful disobedience, and not transgressing, then, Allah is Oft-Forgiving, the Most Merciful (the One that sends the Glorious light of Mercy." (16/An-Nabl: 115)

Surah Al-Maidah: 90 regarding gambling (maysir),

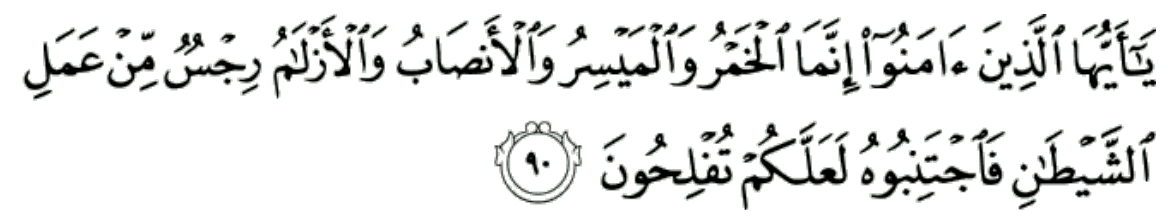

Translation: "O you who believe! intoxicants and games of chance and (sacrificing to) stones set up and (dividing by) arrows are only an uncleanness, the Shaitan's work; shun it therefore that you may be successful.” (5 Al-Maidah:90)

Surah Al-Baqarah: 188 regarding fraud (gharar), dishonesty,

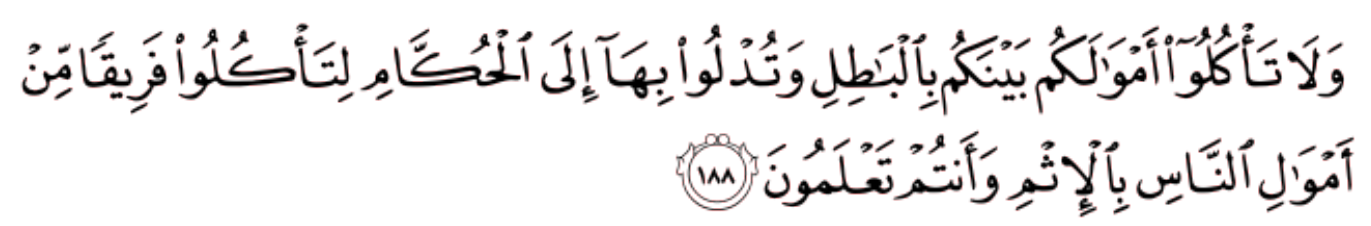

Translation: "O you who believe! Have piety towards Allah and relinquish what remains from usury, if you are (true: "Do not eat up one another's property among yourselves by false means (unjustly) nor give bribery to the judges so that you may knowingly eat up a part of the property of others sinfully." (2/ AlBaqarab:188)

Surah Al-Baqarah: 278 Regarding Riba,

JMIF: Journal of Management and Islamic Finance

Volume 1, Number 1, June 2021, pp. 1-13 


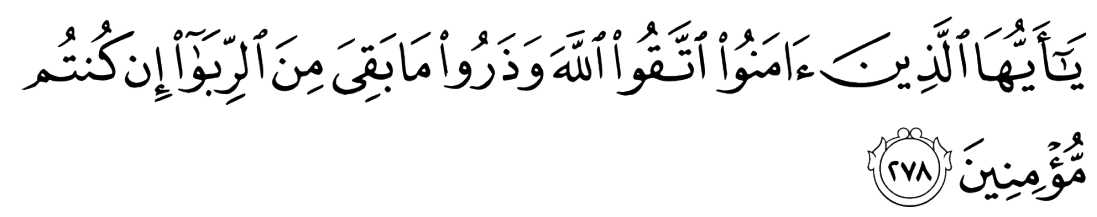

Translation: "O you who believe! Have piety towards Allah and relinquish what remains from usury, if you are (true) believers." (2/ Al-Baqarab: 278)

Surah Al-Baqarah: 195 regarding Infaq and Shodaqoh,

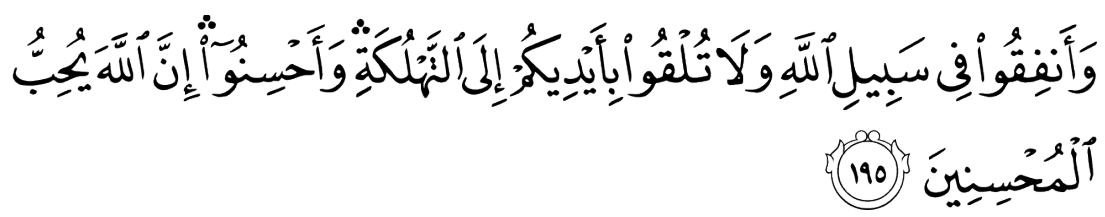

Translation: "And give (your property) in the Way of Allah (to others) and do not throw yourselves into danger and become the best of the best, surely Allab loves the good-doers ("Mubsinun" those who have submitted their physical bodies to Allab)." (2/ Al-Baqarah: 195)

Surah At-Talaq: 7 regarding crisis,

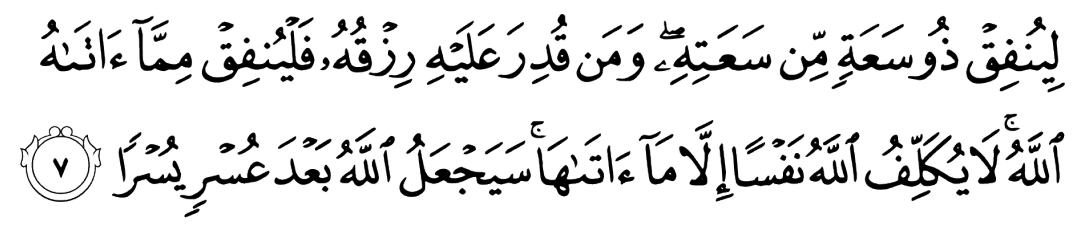

Translation: "A man of vast means should spend according to his vast means. And anyone whose sustenance is limited should spend from whatever Allah has given to him. Allah makes no one liable beyond what He has given to bim. Allah will soon bring ease after a difficulty." (65/ At-Talaq: 7)

\section{METHOD}

This study is qualitative research. The qualitative method emphasizes the observation of phenomena and examines the substance of the meaning of these phenomena. The focus of qualitative research is on the process and the meaning of the results. Qualitative research is focused on elements of objects and institutions as well as relationships or interactions among these elements to understand an event, behavior, or phenomenon (Ardianto, 2020).

This study obtained data from 20 food sellers in the tourism destinations of Ponggok and Janti, Klaten. Researchers conducted interviews with respondents based on the Quran regarding the review of Islamic economics in doing sharia business. Researchers conducted in-depth interviews of their efforts in business. The researcher asked some questions about the conditions before and after the pandemic and sales during the pandemic because to describe the effect of the pandemic on the halal food business. The researcher also provided the provisions regarding the halal food business following the Quran and its relationship with what businesses can and cannot 
run in an Islamic economic review. It is expected that the seller provides clear information about halal food products they sell to buyers in the Ponggok and Janti, Klaten.

\section{RESULTS AND DISCUSSION}

Direct interviews were carried out especially to the sellers in Ponggok and Janti, Klaten tourism destinations. The sellers were interviewed in-depth regarding the halal food business as well as food and drink on their menu. Researchers also asked several questions about the making process, ingredients, and so on. They were asked related to how they produced each day, especially during the pandemic and before the pandemic, which hopefully could be a comparison of their condition in encountering the current pandemic. The researcher asked several criteria that would be used as a benchmark and an overview of Islamic economics to drawing conclusion a conclusion later.

The results of the study were carried out by asking various questions according to indicators based on previous research about halal products, gharar, maysir, infaq and sodaqoh. The researchers also added about riba and the Dalil of spaciousness or crisis that had been prepared by researchers. 20 respondents ran various businesses of halal food and drinks such as hyped drinks, fruit ice, fried chicken, lotek stalls, grocery stores, chicken noodles and meatballs, soup, angkringan and fishing, satay, and other halal food menus in terms of their sales during and before the pandemic. The results can be seen in Table 1 .

Table 1. Research Results

\begin{tabular}{|c|c|c|c|c|}
\hline Indicator & Dalil & Criteria & Yes & No \\
\hline 1 & QS. Al-Baqarah:168 & Halal and Thoyyib Food & $\checkmark$ & \\
\hline 2 & QS. An-Nahl: 115 & Haram Food & & $\checkmark$ \\
\hline 3 & QS. Al-Maidah: 90 & Maysir & & $\checkmark$ \\
\hline 4 & QS. Al-Baqarah:188 & Gharar & & $\checkmark$ \\
\hline 5 & QS. Al-Baqarah: 278 & $\begin{array}{l}\text { LKS Loans/Margin/Non- } \\
\text { Riba }\end{array}$ & $\checkmark$ & \\
\hline 6 & QS. Al-Baqarah: 195 & Infaq and Shodaqob & $\checkmark$ & \\
\hline 7 & QS At-Talaq: 7 & Pandemic/Crisis & $\checkmark$ & \\
\hline
\end{tabular}

Sumber: Data Processed (2021)

The first indicator of halal and thoyyib food is explained in the word of Allah that reads " $\mathrm{O}$ mankind! Eat of that which is lawful and clean on earth, and do not follow the footsteps of Satan (Satan) Verily, he is to you an open enemy (Surah Al-Baqarah: 168). The results for this indicator showed that all sellers sell halal and thoyyib ingredients. They did not use harmful preservatives for 
making meatballs, use natural dyes such as turmeric for fried chicken, and slaughter by calling the name of Allah. However, they did not have halal certification. They were constrained by costs. Sellers sell halal food and drinks since Islamic law does not allow selling non-halal food and drinks. They are in running a business because of Allah Almighty and they did not want the buyer to be harmed in the future. This indicator revealed that they ran a halal food business.

The second indicator was haram food. In the word of Allah Almighty, "He has only forbidden you what is dead, blood, flesh of swine and animal which is slaughtered in the name of others than Allah. However, if one is forced by necessity (to eat), without willful disobedience, and not transgressing, then, Allah is the Most Forgiving, the Most Merciful (the One that sends the Glorious light of Mercy." (Surah An-Nahl: 115). All respondents did not sell haram food, be it pork, blood, and carcasses. They did not use pork in making meatballs, they used goat/chicken meat in making satay, angkringan did not contain frozen blood. This indicator is very necessary so the seller can avoid sin and in the future, no one will sell haram food.

The third indicator, maysir (gambling), as in the word of Allah Almighty that reads " $\mathrm{O}$ you who believe! Intoxicants and games of chance and (sacrificing to) stones set up and (dividing by) arrows are only an uncleanness, the Satan's work; shun it therefore that you may be successful." (Surah Al-Maidah: 90). All sellers did not practice maysir (gambling), did not speculate on prices to consumers, and did not provide gambling facilities. They know that gambling is not allowed in Islam. Food vendors or stalls there also avoid gambling.

The fourth indicator is gharar (fraud. In the word of Allah Almighty, it reads "O you who believe! Have piety towards Allah and relinquish what remains from usury, if you are (true: "Do not eat up one another's property among yourselves by false means (unjustly) nor give bribery to the judges so that you may knowingly eat up a part of the property of others sinfully." (Surah AlBaqarah: 188). All sellers did not commit fraud (gharar), especially the prices they apply to buyers. They did not give inappropriate prices or the food ingredients they sell did not contain chemicals that can harm their consumers. Some consumers become loyal customers, such the consumers of fried chicken.

The fifth indicator is riba. This explains how riba is not allowed in Islam. Thus, in the future, they will runa business well. This is in accordance with the word of Allah Almighty. "O you who believe! Have piety towards Allah and relinquish what remains from usury, if you are (true) believers." (Surah al-Baqarah: 278). Some sellers have directly provided the answer that they borrowed funds from conventional banks in the form of financing and service cooperation, for example, BRI Bank and Cooperative Credit. Some used their own capital for the business. It is worth noting that in the Ponggok and Janti, Klaten, there are still few sellers who know Islamic 
financial institutions, there is only one person who used Islamic microfinance institutions from several respondents interviewed by researchers. Hence, this becomes homework for Islamic financial institutions to implement inclusive finance in places or tourism destinations. It is expected that the economy in the destinations will encourage the creation of Islamic financial institutions with the trading and fisheries sector collaborating with village or regional governments to develop the halal industry and halal tourism.

The sixth Indicator is about Infaq and Shodaqoh as in the word of Allah Almighty "And give (your property) in the Way of Allah (to others) and do not throw yourselves into danger and become the best of the best, surely Allah loves the good-doers ("Muhsinûn" those who have submitted their physical bodies to Allah)." (Surah Al-Baqarah: 195). All sellers did infaq every time they go to the mosque. They also did infaq in the charity box that has been entrusted to them through the ZIS agency. This indicates that in addition to running their business, they also remember those who need it so that their business will be good in the future.

The seventh indicator is related to pandemic/crisis. This is in accordance with the word of Allah Almighty, "A man of vast means should spend according to his vast means. And anyone whose sustenance is limited should spend from whatever Allah has given to him. Allah makes no one liable beyond what He has given to him. Allah will soon bring ease after a difficulty" (Surah At-Talaq: 7). There will be fluctuation in the food business. Fortune has been given by Allah Almighty, thus we should keep being patient and keep trying. Almost all sellers experienced a decrease in turnover of $10-70 \%$ from the turnover before the pandemic. There were even some sellers who did not get any income at all on weekdays. Thus, they had to accept the income they earned even though it was little, but they chased sales turnover on weekends. Their income was very different from before the pandemic occurred.

This also happened to meatball sellers who had to reduce the production of $20 \mathrm{~kg}$ of meatballs to only $12 \mathrm{~kg}$. Grocery sellers decreased sales turnover by $10 \%$, chicken shop sellers reduced production capacity from $30 \mathrm{~kg}$ to $10 \mathrm{~kg}$, satay sellers was difficult to get sales on weekdays. There are even those who have decreased their turnover and have to close their outlets/stalls. Fishing stalls/restaurants decreased by $20-50 \%$. Some have sold assets to cover all sales activities because profits are decreasing. The comparison of before and after the COVID-19 pandemic that occurred in Indonesia was significant. It had an impact on the halal food business, especially in the tourism destinations of Ponggok and Janti, Klaten.

\section{CONCLUSION}

The trend of the halal food business currently encounters various problems during the pandemic. It is expected that halal food sellers can survive during the pandemic. Sellers in the 
Ponggok and Janti tourism destinations have run a halal food business according to Islamic law. They did not sell haram food. They also did infaq and shodaqoh. However, there are still sellers who did not use Islamic financial services in running their business. They used conventional bank loans to run their businesses. They also did not have halal certification since they were constrained by costs. Their sales turnover decreased.

It is expected that government can develop the halal and thoyyib industry to make these destinations a potential tourism destination in Klaten Regency. The government is expected to support halal food sellers. Thus, the economy of the people will improve soon. The government is also expected to facilitate halal certification and development of tourism village-based sharia financial institutions. The next recommendation is to research other tourism destinations for the development of the halal industry and recommendations for halal food sellers to continue to sell halal food and products to consumers and to improve the economic development of communitybased tourism villages, especially after the pandemic is over. Hence, the economy will be improved in the future.

\section{REFERENCES}

Afandi, Y. (2009). Fiqh Muamalah dan Implementasinya dalam Lembaga Keuangan Syariah.

Ardianto, Y. (2020). Memahami Metode Penelitian Kualitatif. In DJKN Kementerian Keuangan.

BPOM. (2020). Cek Produk BPOM RI. In www.cekbpom.pom.go.id.

Fatmasari Sukesti, \& Mamdukh Budiman. (2014). the Influence Halal Label and Personal Religiousity on Purchase. International Journal of Business, Economics and Law, 4(1), 2012-2015.

Jaelani, A. K., Handayani, I. G. A. K. R., \& Karjoko, L. (2020). Development of halal tourism destinations in the Era of regional autonomy in West Nusa Tenggara Province. International Journal of Innovation, Creativity and Change, 12(12), 765-774.

Janti, I. S. (2020). Peran Omotenashi Dalam Meningkatkan Makanan Halal Di Jepang. Sosiologi Reflektif, 14(2), 389-405.

Kemenhan, R. (2014). UU Nomor 33 Tabun 2014 Tentang Jaminan Produk Halal.

LPPOM. (2019). Sertifikasi Halal MUI Periode 2012-2019,. In wmw.halalmui.org.

Marzuki, I., \& Ramdaniah, F. (2020). Strategi Pemasaran Pedagang Sembako Dalam Meningkatkan Taraf Ekonomi Perspektif Ekonomi Islam. Iqtishadia Jumal Ekonomi Dan Perbankan Syariah, 6(1), https://10.19105/iqtishadia.v6i1.2139. https://doi.org/10.19105/iqtishadia.v6i1.2139

Musa, K. (2006). Ensiklopedi Halal-Haram dalam Makanan dan Minuman.

Nasrullah, A. (2018). Analisis Potensi Industri Halal Bagi Pelaku Usaha di Indonesia. At-Tabdrib Jurnal Studi Islam Dan Muamalah Kopertais 4, 50-78. 
Nurohman, Y. A., \& Qurniawati, R. S. (2019). Keputusan Pembelian Produk Makanan Halal Di Lingkungan IAIN Surakarta. Among Makarti, 12(24), 23-33.

Setiawan, S., \& Mauluddi, H. A. (2019). Perilaku Konsumen Dalam Membeli Produk Halal Di Kota Bandung. At-Tijaroh: Jurnal Ilmu Manajemen Dan Bisnis Islam, 5(2), 232-246. https://doi.org/10.24952/tijaroh.v5i2.1849

Ulum, B. (2018). Implementasi Prinsip Ekonomi Islam Oleh Pedagang. 05, 381-396.

Wahyono, Z., \& Razak, M. A. A. (2020). Islamic Tourism in Southeast Asia: The Concept and its Implementation. International Journal of Halal Research, 2(2), 90-105. https://doi.org/10.18517/ijhr.2.2.90-105.2020

Wan-Hassana, W. M., \& Awangb, K. W. (2009). Halal food in New Zealand restaurants: An exploratory study. International Journal of Economics and Management, 3(2), 385-402.

Warto A.S. (2020). Bisnis Produk Halal antara Peluang dan Tantangan, Problematika dan Halal Product Business Between Opportunities and Challenges, Problematics and Their Solutions Bisnis Produk Halal antara Peluang dan Tantangan, Problematika dan Solusinya Author corresp. Al-Ulum, 20(1), 274-294.

Zahrah, A., \& Fawaid, A. (2019). Halal Food di Era Revolusi Industri 4.0: Prospek dan Tantangan. Hayula: Indonesian Journal of Multidisciplinary Islamic Studies, 3(2), 121-138. https://doi.org/10.21009/hayula.003.2.01 